\title{
PENGARUH STORE IMAGE TERHADAP KEPUTUSAN PEMBELIAN KOSUMEN PADA KRISNA 5 SINGARAJA
}

\author{
Gede Wahyu Maharta ${ }^{1}$, Made Ary Meitriana ${ }^{2}$, Anjuman Zukhri $^{3}$ \\ Jurusan Pendidikan Ekonomi \\ Universitas Pendidikan Ganesha \\ Singaraja, Indonesia \\ e-mail : wahyumaharta21@gmail.com, ary.meitriana@yahoo.co.id, \\ anjuman.zukhri@undiksha.ac.id
}

\begin{abstract}
Abstrak
Penelitian ini bertujuan untuk mengetahui Pengaruh fasilitas fisik, barang dagangan, kenyamanan dan pelayanan baik secara parsial maupun simultan terhadap keputusan pembelian konsumen pada Krisna 5 Singaraja. Penelitian ini termasuk jenis penelitian kausal. Subjek dalam penelitian ini adalah konsumen yang dijumpai pada Krisna 5 Singaraja yang berjumlah 100 orang. Data dikumpulkan dengan menggunakan kuesioner dan dianalisis menggunakan analisis regresi linier berganda dengan bantuan program statistical package for social sciences (SPSS) for windows versi 16. Hasil penelitian menunjukkan fasilitas fisik berpengaruh signifikan terhadap keputusan pembelian ditunjukkan dari nilai $t_{\text {hitung }}>t_{\text {tabel }}(6.681>$ 1.66), barang dagangan berpengaruh signifikan terhadap keputusan pembelian ditunjukan dari nilai $t_{\text {hitung }}>t_{\text {tabel }}(1.523>1.66)$, kenyamanan berpengaruh terhadap keputusan pembelian ditunjukkan dari nilai $t_{\text {hitung }}>t_{\text {tabe }} l(14.130>1.66)$, pelayanan berpengaruh terhadap keputusan pembelian ditunjukan dari nilai $t_{\text {hitung }}>t_{\text {tabe }} l$ (1.898 $>$ 1.66), dan Fasilitas fisik, barang dagangan, kenyamanan dan pelayanan berpengaruh terhadap keputusan pembelian ditunjukan dari nilai $F_{\text {hitung }}>F_{\text {tabel }}$ $(121.745>2.74)$.
\end{abstract}

Kata kunci : Store Image, Keputusan Pembelian

\begin{abstract}
This study aims to determine the influence of physical, merchandise, convenience and service either partially or simultaneously to consumer purchasing decisions on Krisna 5 Singaraja. This research includes the type of causal research. Subjects in this study were consumers who found on Krisna 5 Singaraja that requires 100 people. Data using questionnaire and analyzed by using multiple linear regression analysis with the aid of social statistic package program for SPSS for windows version 16 . The result showed physical facility significantly influence purchasing decision > ttable $(6.681>1.66)$, significant merchandise to the purchase decision is shown from the value of tcount $>$ ttable $(1.523>1.66)$, the convenience of the mall to the purchase decision of the tcount> ttable $(14.130>1.66)$, the reproduction service to the purchasing decision is shown from tcount> ttable $(1.898>1.66)$, and Physical facilities, merchandise, convenience and health services to purchase decisions are shown from Fcount> Ftable $(121.745>2.74)$.
\end{abstract}

Keywords : Store Image, Purchase Decision 


\section{PENDAHULUAN}

Persaingan dunia usaha di Bali semakin ketat. Setiap perusahaan bersaing untuk menarik pelanggan dan mempertahankan eksistensinya di pasar, termasuk dalam bidang toko ritel yang saat ini tumbuh dan berkembang pesat seiring dengan meningkatanya pertumbuhan ekonomi di Bali. Adapun yang harus diperhatikan oleh pengusaha adalah keputusan pembelian konsumen. Menurut Schiffman \& Kanuk (2002:437) "keputusan pembelian adalah suatu keputusan seseorang dimana dia memilih salah satu dari beberapa alternatif yang ada." Dari berbagai faktor yang mempengaruhi konsumen dalam melakukan pembelian suatu produk atau jasa, biasanya konsumen selalu mempertimbangkan kualitas, harga dan produk yang sudah dikenal oleh masyarakat sebelum konsumen memutuskan untuk membeli.

Menurut Ruslan (2008:80), image adalah "seperangkat keyakinan, ide, dan kesan seseorang terhadap suatu objek tertentu." Sikap dan tindakan seseorang terhadap suatu objek akan ditentukan oleh citra objek tersebut yang menampilkan kondisi terbaiknya, senada dengan pendapat Kotler (2002:338), image adalah "persepsi masyarakat terhadap perusahaan atau produknya." menurut Alma (2003:92), image merupakan "impresi, perasaan atau konsepsi yang ada pada publik mengenai perusaaan, mengenai suatu object, orang atau mengenai lembaga," dan menuut Simamora (2003:33), image adalah "persepsi yang relatif konsisten dalam jangka waktu panjang, sehingga tidak mudah untuk membentuk citra," citra sekali terbentuk akan sulit untuk mengubahnya, image yang dibentuk harus jelas dan memiliki keunggulan bila dibandingkan dengan pesaingnya, saat perbedaan dan keunggulan merek dihadapkan dengan merek lain. Jadi dapat disimpulkan image adalah suatu pandangan atau persepsi seseorang terhadap suatu objek yang terbentuk melalui kesan serta keadaan objek tersebut.

Menurut Cox \& Brittain (2004:184), store image adalah "kombinasi dari kognisi individu dan respon emosional yang muncul dari persepsi konsumen terhadap toko dan atribut yang dimilikinya serta kenangan dan berbagai hal yang mengingatkan konsumen terhadap toko tersebut." Perpaduan antara fasilitas dan hal penataan tata letak barang di sebuah toko sangat diperlukan sehingga menimbulkan kesan yang menarik bagi konsumen, kombinasi yang baik akan menambah kesan baik serta kenyamanan konsumen yang masuk ke dalam sebuah toko, dari kenyamanan tersebut diharapkan konsumen akan memunculkan niat konsumen untuk memilih produk dengan lebih nyaman sehingga diharapkan konsumen melakukan pembelian, berbeda dengan pendapat Sopian \& Syihabudhi (2008:138), store image adalah "kepribadian toko yang melekat di benak konsumen terhadap sebuah produk atau toko." Kepribadian menggambarkan keadaan dan kesan suatu toko dipikiran konsumen, kepribadian suatu toko yang baik dapat dilihat dari bentuk bangunan, kebersihan ruangan, pelayanan dan keramahan karyawanya senada dengan pendapat tersebut menurut Peter \& Olson (2000:248), store image adalah "suatu gambaran yang dipikirkan konsumen tentang suatu toko termasuk di dalamnya meliputi persepsi dan sikap yang dirasakan pada sensasi dari rangsangan yang berkaitan dengan toko yang diterima melalui panca indra." Konsumen dapat merasakan sensasi di dalam toko baik itu dari aroma, suhu, pencahayaan, keramahan pelayanan, serta tatanan produk yang memudahkan konsumen untuk memilih di dalam ruangan toko sehingga menciptakan citra ataupun kesan baik bagi konsumen. Lebih lanjut menurut Simamora (2003:160), store image adalah "kesan yang diterima konsumen dari toko yang menjual produk, diukur berdasarkan kualitas yang dirasakan dari pengecer dimana produk yang bermerek tersedia," dan menurut Utami (2010:270), store image adalah "gambaran keseluruhan yang lebih dari sekedar penjumlahan perbagian, dimana masing-masing bagian berinteraksi satu sama lain dalam pikiran konsumen, sedangkan menurut Maxwell \& Scott 
Swanson (2009:132), store image adalah "kesan yang diinterprestasikan dalam kesan sebagai hasil dari kelengkapan yang dirasakan konsumen yang berhubungan dengan toko serta saling bergantung dalam kesan konsumen yang berdasarkan paparan baik saat ini maupun sebelumnya." Store image merupakan gambaran jiwa atau kepribadian toko yang oleh pemiliknya berusaha disampaikan kepada pelanggan. Menurut Sopian \& Syihabudhi (2008:138), Store image adalah "Kepribadian toko yang melekat di benak konsumen terhadap sebuah produk atau toko." Kepribadian atau image toko menggambarkan apa yang dilihat dan dirasakan oleh konsumen terhadap toko tertentu. Bagi konsumen, kepribadian itu juga mewakili suatu gambaran dan merancang apa yang diinginkan, dilihat, dan dirasakan oleh konsumen terhadap toko tertentu. Adapun beberapa hal yang merupakan bagian dari store image menurut Berman \& Evans (2001:51) "yaitu :fasilitas fisik, barang dagangan, kenyamanan, dan pelayanan. Store image dijadikan sebagai kepribadian toko yang membedakan toko satu dengan toko yang lain yang dipersepsikan oleh konsumen." Konsumen dapat mengingat dengan baik, bila suatu toko yang pernah didatangi memiliki image positif sehingga konsumen tertarik kembali melakukan keputusan pembelian di toko tersebut.

Sebagai salah satu toko di Singaraja, Krisna 5 Singaraja memiliki lokasi yang strategis, terletak pada akses jalan Seririt Singaraja yang banyak dilalui aktifitas masyarakat, memiliki lahan yang luas, bersih serta desain exterior dan interior toko yang berbeda dilihat dari penataan di depan area toko yang menghadap ke jalan raya dengan hiasan patung - patung yang cukup menarik, dilengkapi dengan dua buah pos keamanan security yang menambah rasa aman pengunjung dan memudahkan pengunjung yang hendak masuk dan keluar area toko yang sudah di pandu oleh security ketika menyebrang jalan, kemudian masuk ke lahan parkir yang luas dan desain bangunan toko yang cukup rapi dan bersih sehingga dapat menarik minat konsumen untuk masuk dan melihat - lihat ke dalam toko, dan tentunya diharapkan akan terjadi impulsive buying yang dikarenakan desain interior toko yang indah dan nyaman, serta memiliki display dan lay out yang tertata rapi, ditambah dengan fasalitas umum yang menyediaka berbagai kebutuhan, misalnya dengan pembayaran menggunakan kartu kredit, serta adanya mesin atm untuk memudahkan pengambilan uang, pos keamanan yang dapat menumbuhkan rasa nyaman dan aman di benak konsumen, sehingga menimbulkan kesan citra atau imgae toko yang baik bagi konsumen.

Krisna 5 Singaraja merupakan toko yang telah dikenal oleh masyarakat, toko tersebut telah berkembang pesat terlebih dahulu di kawasan Denpasar yang merupakan daerah pariwisata di Bali, meskipun telah memiliki image atau citra yang baik pada masyrakat, tetapi pada saat dilakukan survey terlihat bahwa ada beberapa pengunjung hanya masuk dan melihat - lihat produk yang dijual pada Krisna 5 Singaraja tanpa melakukan pembelian, oleh sebab itu peneliti tertarik untuk mengetahui seberapa besar pengaruh Store image terhadap keputusan pembelin konsumen, sehingga mengangkat judul "Pengaruh Store Image Terhadap Keputusan Pembelian Konsumen Pada Krisna 5 Singaraja”.

\section{METODE}

Penelitian ini merupakan penelitian kuantitatif kausal, dimana pendekatan kuantitatif mementingkan adanya variabel yang didefinisikan dalam bentuk oprasional variabel masing - masing. Desain kausal yang artinya sifat dan hubungan variabel tersebut menunjukan adanya sebab akibat. Desain kausal digunakan digunakan untuk mengukur kuat hubungan dan pengaruh variabel dalam penelitian (Darsono, 2001). Adapun variabel dari penelitian ini yaitu store imgae yang terdiri dari Fasilitas fisik (X1), Barang dagangan (X2), Kenyamanan (X3), pelayanan (X4), dan keputusan pembelian (Y). hasil yang diharapkan dari penelitian ini adalah untuk mengetahui adanya pengaruh store image terhadap 
p-ISSN : 2599-1418

e-ISSN : 2599-1426
Jurnal Pendidikan Ekonomi Undiksha

Volume 10 No. 1 Tahun 2018 keputusan pembelian konsumen pada Krisna Oleh - Oleh Khas Bali Singaraja.

Metode pengumpulan data untuk memperoleh data kuesioner dilakukan dengan menyebar formulir - formulir yang berisi pertanyaan-pertanyaan yang diajukan secara tertulis pada seseorang atau sekumpulan orang untuk mendapatkan jawaban atau tanggapan dan informasi yang diperlukan oleh peneliti, dimana daftar pertanyaan dibuat secara berstruktur dengan bentuk pertanyaan pilihan berganda (multiple choice questions) dan pertanyaan terbuka (open question). Untuk memperoleh data tentang pengaruh store image terhadap keputusan pembelian konsumen, instrumen pengumpulan data yang dipergunakan berupa angket atau kuesioner.

Teknik analisis data penelitian ini menggunakan metode analisis regresi linier berganda dengan rumus $\hat{Y}=a+b_{1}$ $X_{1}+b_{2} X_{2}+b_{3} X_{3}+b_{4} X_{4}+e$, yang terdiri dari uji t, uji $f$, persamaan regresi dan koefisien determinasi dengan menggunakan program komputer software SPSS 16.0 Windows

\section{HASIL DAN PEMBAHASAN \\ Hasil Penelitian}

Berdasarkan perhitungan analisis data, dapat dilihat pada tabel 1

Tabel 1. Hasil uji t untuk variabel fasilitas fisik

Coefficients $^{a}$

\begin{tabular}{|c|c|c|c|c|c|c|}
\hline \multirow{2}{*}{\multicolumn{2}{|c|}{ Model }} & \multicolumn{2}{|c|}{$\begin{array}{l}\text { Unstandardized } \\
\text { Coefficients }\end{array}$} & \multirow{2}{*}{$\begin{array}{c}\text { Standardized } \\
\text { Coefficients } \\
\text { Beta }\end{array}$} & \multirow[b]{2}{*}{$\mathrm{T}$} & \multirow[b]{2}{*}{ Sig } \\
\hline & & B & Std. Error & & & \\
\hline \multirow[t]{2}{*}{1} & (Constant) & -3.151 & 2.065 & & -1.526 & .130 \\
\hline & $\begin{array}{l}\text { Fasilitas } \\
\text { fisik }\end{array}$ & .441 & .066 & .310 & 6.681 & .000 \\
\hline
\end{tabular}

Berdasarkan pengujian hipotesis dilakukan dengan jumlah sampel 100 orang konsumen, sehingga dapat diperoleh $\mathrm{df}=\mathrm{n}-\mathrm{k}=100-5=95$, sehingga $t_{\text {tabel }}$ dengan df 95 adalah sebesar 1.66 berdasarkan analisis pada tabel 1 memperlihatkan bahwa variabel fasilitas fisik berpengaruh secara signifikan terhadap keputusan pembelian, karena nilai $t_{\text {hitung }}=6.681>t_{\text {tabel }}=1.66$ atau $\mathrm{p}$ value $=0.000<\mathrm{a}=0.05$ maka $\mathrm{H}_{0}$ ditolak. Oleh karena itu, maka dapat disimpulkan bahwa variabel fasilitas fisik memiliki pengaruh yang signifikan terhadap keputusan pembelian konsumen pada Krisna 5 Singaraja.

Berdasarkan perhitungan analisis data, dapat dilihat pada tabel 2

Tabel 2. Hasil uji t untuk variabel barang dagangan

Coefficients $^{a}$

\begin{tabular}{|c|c|c|c|c|c|c|}
\hline \multirow{2}{*}{\multicolumn{2}{|c|}{ Model }} & \multicolumn{2}{|c|}{$\begin{array}{l}\text { Unstandardized } \\
\text { Coefficients }\end{array}$} & \multirow{2}{*}{$\begin{array}{c}\text { Standardized } \\
\text { Coefficients } \\
\text { Beta }\end{array}$} & \multirow[b]{2}{*}{$\mathrm{T}$} & \multirow[b]{2}{*}{ Sig. } \\
\hline & & $\mathrm{B}$ & Std. Error & & & \\
\hline \multirow[t]{2}{*}{1} & (Constant) & -3.151 & 2.065 & & -1.526 & .130 \\
\hline & $\begin{array}{l}\text { Barang } \\
\text { dagangan }\end{array}$ & .120 & .079 & .080 & 1.523 & .000 \\
\hline
\end{tabular}

Berdasarkan pengujian hipotesis dilakukan dengan jumlah sampel 100 orang konsumen, sehingga dapat diperoleh $\mathrm{df}=\mathrm{n}-\mathrm{k}=100-5=95$, sehingga $t_{\text {tabe }} l$ dengan df 95 adalah sebesar 1.66 berdasarkan analisis pada tabel 2 memperlihatkan bahwa variabel barang dagangan berpengaruh secara signifikan terhadap keputusan pembelian, karena nilai $t_{\text {hitung }}=1.523>t_{\text {tabel }}=1.66$ 
p-ISSN : 2599-1418

e-ISSN : 2599-1426
Jurnal Pendidikan Ekonomi Undiksha

Volume 10 No. 1 Tahun 2018 atau $p$ value $=0.000<\mathrm{a}=0.05$ maka $\mathrm{H}_{0}$ ditolak. Oleh karena itu, maka dapat disimpulkan bahwa variabel barang dagangan memiliki pengaruh yang signifikan terhadap keputusan pembelian konsumen pada Krisna 5 Singaraja

Berdasarkan perhitungan analisis data, dapat dilihat pada tabel 3

Tabel 3 Hasil uji t untuk variabel kenyamanan

Coefficients $^{a}$

\begin{tabular}{|c|c|c|c|c|c|c|}
\hline \multirow[b]{2}{*}{ Model } & & \multicolumn{2}{|c|}{$\begin{array}{l}\text { Unstandardized } \\
\text { Coefficients }\end{array}$} & \multirow{2}{*}{$\begin{array}{c}\text { Standardized } \\
\text { Coefficients } \\
\text { Beta } \\
\end{array}$} & \multirow{3}{*}{$\begin{array}{l}\mathrm{T} \\
-1.526\end{array}$} & \multirow{3}{*}{$\frac{\text { Sig. }}{.130}$} \\
\hline & & $\mathrm{B}$ & Std. Error & & & \\
\hline 1 & (Constant) & -3.151 & 2.065 & & & \\
\hline & $\begin{array}{l}\text { Kenyaman } \\
\text { an }\end{array}$ & 1.370 & .097 & .664 & 14.130 & .000 \\
\hline
\end{tabular}

Berdasarkan pengujian hipotesis dilakukan dengan jumlah sampel 100 orang konsumen, sehingga dapat diperoleh $\mathrm{df}=\mathrm{n}-\mathrm{k}=100-5=95$, sehingga $t_{\text {tabel }}$ dengan df 95 adalah sebesar 1.66 berdasarkan analisis pada tabel 3 memperlihatkan bahwa variabel kenyamanan berpengaruh secara signifikan terhadap keputusan pembelian, karena nilai $t_{\text {hitung }}=14.130>t_{\text {tabel }}=1.66$ atau $\mathrm{p}$ value $=0.000<\mathrm{a}=0.05$ maka $\mathrm{H}_{0}$ ditolak. Oleh karena itu, maka dapat disimpulkan bahwa variabel kenyamanan memiliki pengaruh yang signifikan terhadap keputusan pembelian konsumen pada Krisna 5 Singaraja.

Berdasarkan perhitungan analisis data, dapat dilihat pada tabel 4

Tabel 4. Hasil uji t untuk variabel pelayanan

Coefficients $^{a}$

\begin{tabular}{|c|c|c|c|c|c|c|}
\hline \multirow{2}{*}{\multicolumn{2}{|c|}{ Model }} & \multicolumn{2}{|c|}{$\begin{array}{l}\text { Unstandardized } \\
\text { Coefficients }\end{array}$} & \multicolumn{2}{|l|}{$\begin{array}{l}\text { Standardized } \\
\text { Coefficients }\end{array}$} & \multirow[b]{2}{*}{ Sig. } \\
\hline & & B & Std. Error & Beta & $\mathrm{T}$ & \\
\hline \multirow[t]{2}{*}{1} & (Constant) & -3.151 & 2.065 & & -1.526 & .130 \\
\hline & Pelayanan & .281 & .148 & .098 & 1.898 & .000 \\
\hline
\end{tabular}

Berdasarkan pengujian hipotesis dilakukan dengan jumlah sampel 100 orang konsumen, sehingga dapat diperoleh $\mathrm{df}=\mathrm{n}-\mathrm{k}=100-5=95$, sehingga $t_{\text {tabel }}$ dengan df 95 adalah sebesar 1.66 berdasarkan analisis pada tabel 4 memperlihatkan bahwa variabel pelayanan berpengaruh secara signifikan terhadap keputusan pembelian, karena nilai $t_{\text {hitung }}=1.898>t_{\text {tabel }}=1.66$ atau $p$ value $=0.000<\mathrm{a}=0.05$ maka $\mathrm{H}_{0}$ ditolak. Oleh karena itu, maka dapat disimpulkan bahwa variabel kenyamanan memiliki pengaruh yang signifikan terhadap keputusan pembelian konsumen pada Krisna 5 Singaraja.

Berdasarkan perhitungan analisis data, dapat dilihat pada tabel 5 hasil perhitungan dengan menggunakan program komputer software SPSS 16.0 Windows menunjukan hasil dari pengaruh variabel fasilitas fisik, barang dagangan, kenyamanan, dan pelayanan terhadap keputusan pembelian konsumen pada Krisna 5 Singaraja. 
Tabel 5. Hasil perhitungan uji $F$ ANOVA $^{\mathrm{b}}$

\begin{tabular}{|c|c|c|c|c|c|c|}
\hline Model & & $\begin{array}{l}\text { Sum of } \\
\text { Squares }\end{array}$ & Df & Mean Square & $\mathrm{F}$ & Sig. \\
\hline \multirow[t]{3}{*}{1} & Regression & 2657.385 & 4 & 664.346 & 121.745 & $.000^{a}$ \\
\hline & Residual & 518.405 & 95 & 5.457 & & \\
\hline & Total & 3175.99 & 99 & & & \\
\hline
\end{tabular}

Berdasarkan pengujian dapat dilihat bahwa $F_{\text {hitung }}=121.745>F_{\text {tabel }}=2.47$ atau $p$ value $=0.000<\alpha=0,05$ hal ini berarti $\mathrm{H}_{0}$ ditolak. Oleh karena itu, maka dapat disimpulkan bahwa variabel fasilitas fisik, barang dagangan, kenyamanan dan pelayanan berpengaruh secara bersama sama terhadap variabel keputusan pembelian konsumen pada Krisna 5 Singaraja

Berdasarkan perhitungan analisis data, dapat dilihat pada tabel 6

Tabel 6. Hasil Perhitungan Koefisien Determinasi (Adjusted R Square)

Model Summary

\begin{tabular}{lcc}
\hline Model & $\mathrm{R}$ & $\mathrm{R}$ Square \\
\hline 1 & $.915^{\mathrm{a}}$ & .837 \\
\hline
\end{tabular}

Berdasarkan hasil analisis pada tabel 6 dengan menggunakan program SPSS 16.0 for windows menunjukkan bahwa besarnya pengaruh variabel fasilitas fisik, barang dagangan, kenyamanan dan pelayanan terhadap variabel keputusan pembelian sebesar 0.830 sehingga sumbangan pengaruh untuk variabel fasilitas fisik (X1), barang dagangan (X2), kenyamanan (X3) dan pelayanan (X4) terhadap keputusan
Adjusted R Square Std. Error of the Estimate .830

2.33600 pembelian $(\mathrm{Y})$ adalah sebesar $83 \%$. Hal ini berarti keputusan pembelian konsumen pada Krisna 5 Singaraja $83 \%$ dipengaruhi oleh variabel fasilitas fisik, barang dagangan, kenyamanan dan pelayanan, sedangkan sisanya sebesar $17 \%$ dipengaruhi oleh faktor lain yang tidak termasuk dalam penelitian ini. Berdasarkan perhitungan analisis data, dapat dilihat pada tabel 7

Tabel 7 hasil perhitungan uji t untuk variabel fasilitas fisik, barang dagangan, kenyamanan dan pelayanan

Coefficients $^{a}$

\begin{tabular}{|c|c|c|c|c|c|c|}
\hline \multirow{2}{*}{\multicolumn{2}{|c|}{ Model }} & \multicolumn{2}{|c|}{ Unstandardized Coefficients } & $\begin{array}{l}\text { Standardized } \\
\text { Coefficients }\end{array}$ & \multirow[b]{2}{*}{$\mathrm{T}$} & \multirow[b]{2}{*}{ Sig. } \\
\hline & & B & Std. Error & Beta & & \\
\hline 1 & (Constant) & -.3 .151 & 2.065 & & -1.526 & .130 \\
\hline & Fasilitas fisik & .441 & .066 & .310 & 6.681 & .000 \\
\hline & Barang dagangan & .120 & .079 & .080 & 1.523 & .000 \\
\hline & Kenyamanan & .1370 & .097 & .664 & 14.130 & .000 \\
\hline & Pelayanan & .281 & .148 & .098 & 1.898 & .000 \\
\hline
\end{tabular}

Berdasarkan hasil analisis pada tabel 7 dengan mengunakan program SPSS 16.0 for windows dapat dibuat persamaan garis regresi. Persamaan garis regresi yang dapat dibuat untuk menggambarkan pengaruh fasilitas fisik, barang dagangan, kenyamanan serta pelayanan terhadap keputusan 
pembelian. berdasarkan hasil uji t statistik menunjukan bahwa variabel indevendent $\mathrm{X} 1, \mathrm{X} 2, \mathrm{X} 3$ dan $\mathrm{X} 4$ berpengaruh terhadap $Y$, dengan rumus regresi linier berganda, $\hat{Y}=a+b_{1} X_{1}+b_{2} X_{2}+b_{3} X_{3}+b_{4} X_{4}+e$, dan hasil sebagai berikut, $\hat{Y}=-3.151+0.441 X_{1}+0.120 X_{2}+1.370$ $\mathrm{X}_{3}+0.281 \mathrm{X}_{4}$

Keterangan :

$$
\begin{array}{ll}
\hat{Y} & =\text { Keputusan pembelian } \\
\mathrm{X}_{1} & =\text { Fasilitas fisik } \\
\mathrm{X}_{2} & =\text { Barang dagangan } \\
\mathrm{X}_{3} & =\text { Kenyamanan } \\
\mathrm{X}_{4} & =\text { Pelayanan }
\end{array}
$$

Berdasarkan hasil analisis data pada tabel 7 dapat dilihat bahwa Konstanta 3.151 menunjukkan bahwa jika variabel fasilitas fisik, barang dagangan, kenyamanan dan pelayanan sama dengan nol, maka keputusan pembelian mengalami kenaikan sebesar -3.151 satuan. Koefisien regresi 0.441 berarti jika variabel fasilitas fisik (X1) meningkat tiap satu satuan, maka keputusan pembelian (Y) akan mengalami peningkatan sebesar 0.441 dengan syarat variabel bebas lainnya tetap. Koefisien regresi 0.120 berarti jika variabel barang dagangan (X2) meningkat tiap satu satuan, maka keputusan pembelian $(\mathrm{Y})$ akan mengalami peningkatan sebesar 0.120 dengan syarat variabel bebas lainnya tetap. Koefisien regresi 0.1370 berarti jika variabel kenyamanan (X3) meningkat tiap satu satuan, maka keputusan pembelian (Y) akan mengalami peningkatan sebesar 0.1370 dengan syarat variabel bebas lainnya tetap. Koefisien regresi 0.281 berarti jika variabel pelayanan (X4) meningkat tiap satu satuan, maka keputusan pembelian ( $\mathrm{Y}$ ) akan mengalami peningkatan sebesar 0.281 dengan syarat variabel bebas lainnya tetap. Persamaan regresi linier berganda menunjukan bahwa fasilitas fisik, barang dagangan, kenyamanan dan pelayanan berpengaruh positif terhadap keputusan pembelian konsumen pada Krisna 5 Singaraja

\section{Pembahasan}

Berdasarkan hasil penelitian yang dilakukan mengenai pengaruh store image terhadap keputusan pembelian konsumen pada Krisna 5 Singaraja. Temuan ini mendukung teori yang dikemukakan Sopian \& Syihabudhi (2008:138), store image adalah "kepribadian toko yang melekat di benak konsumen terhadap sebuah produk atau toko." Senada dengan teori tersebut Maxwell \& Scott Swanson (2009:132), store image adalah "kesan yang diinterprestasikan dalam kesan sebagai hasil dari kelengkapan yang dirasakan konsumen yang berhubungan dengan toko serta saling bergantung dalam kesan konsumen yang berdasarkan paparan baik saat ini maupun sebelumnya." Store image merupakan gambaran jiwa atau kepribadian toko yang oleh pemiliknya berusaha disampaikan kepada pelanggan. Sementara bagi pelanggan, store image merupakan sikap individu dari toko tersebut.

Kepribadian menggambarkan keadaan dan kesan suatu toko dipikiran konsumen, kepribadian suatu toko yang baik dapat dilihat dari bentuk bangunan, kebersihan ruangan, pelayanan dan keramahan karyawanya. Citra atau image toko dipengaruhi oleh periklanan yang dilakukan, pelayanan, kesenangan, layout toko dan personil toko sebagaimana halnya dengan kualitas, harga, keragaman dan kedalaman barang dagangan, konsumen akan cenderung berbelanja di toko yang sesuai dengan image yang dibangunya.

Hasil penelitian ini menunjukan bahwa fasilitas fisik, barang dagangan atau produk, kenyamanan serta pelayanan memiliki pengaruh positif terhadap keputusan pembelian konsumen pada Krisna 5 Singaraja. Fasilitas fisik merupakan komponen utama dalam membentuk kesan sebuah toko dan dalam membantu toko tersebut dalam menjual barang-barangnya. Lokasi, tempat parkir, ruang panjang yang memudahkan konsumen mendapatkan barang, arsiektur dan pewarnaan ruang yang menarik mempunyai peranan yang sangat penting untuk memberikan sebuah daya tarik sehingga bisa mendorong keinginan membeli konsumen.

Fasilitas fisik mempunyai kaitan yang erat untuk mendorong keinginan konsumen dalam melakukan keputusan pembeliankonsumen. Hasil penelitian ini sejalan dengan pendapat Sumayang 
(2003:124) fasilitas adalah "penyediaan perlengkapan fisik yang memberikan kemudahan kepada konsumen untuk melakukan aktivitasnya sehingga kebutuhan konsumen dapat terpenuhi." Sejalan dengan teori tersebut menurut Tjiptono (2004:19) fasilitas adalah "sumber daya fisik yang harus ada sebelum jasa ditawarkan kepada konsumen." Fasilitas merupakan sesuatu yang sangat penting dalam usaha jasa, oleh karena itu fasilitas yang ada yaitu kondisi fasilitas, kelengkapan desain interior dan eksterior serta kebersihan fasilitas harus dipertimbangkan terutama yang berkaitan erat dengan apa yang dirasakan konsumen secara langsung. Fasilitas merupakan suatu jasa pelayanan yang disediakan oleh suatu toko untuk menunjang atau mendukung aktivitas aktivitas konsumen yang berkunjung pada toko tersebut. Apabila suatu toko memiliki fasilitas yang memadai serta memenuhi standar pelayanan dan dapat memuaskan pengunjung maka dapat menarik pengunjung lebih banyak lagi melalui kesan - kesan baik dari pengunjung sebelumnya untuk melakukan keputusan pembelian.

Barang dagangan atau produk memiliki pengaruh positif terhadap keputusan pembelian konsumen pada Krisna 5 Singaraja. Barang dagangan atau produk merupakan elemen kunci dalam keseluruhan penawaran pasar. Perencanaan bauran pemasaran dimulai dengan merumuskan penawaran yang memberikan nilai bagi pelanggan sasaran. Menurut Sangadji

(2013:15) mengemukakan bahwa "barang dagangan atau produk adalah segala sesuatu yang dapat ditawarkan di pasar untuk memenuhi kebutuhan dan keinginan konsumen". Produk memiliki arti penting bagi perusahaan karena tanpa adanya produk perusahaan tidak dapat melakukan apapun dari usahanya. Konsumen akan membeli produk bila merasa cocok, karena itu produk harus disesuaikan dengan keinginan ataupun kebutuhan pembeli agar pemasaran produk berhasil.

Kenyamanan meiliki pengaruh positif terhadap keputusan pembelian konsumen pada Krisna 5 Singaraja. Kenyamanan dan perasaan nyaman adalah penilaian komprehensif seseorang terhadap lingkungannya. Manusia menilai kondisi lingkungan berdasarkan rangsangan yang masuk ke dalam dirinya. Dalam hal ini yang terlibat tidak hanya masalah fisik biologis, namun juga perasaan, suara, cahaya, aroma, suhu dan lain-lain rangsangan ditangkap sekaligus, lalu diolah oleh otak, kemudian otak akan memberikan penilaian relatif apakah kondisi itu nyaman atau tidak.

Dalam menciptakan kesan yang baik untuk sebuah toko maka diperlukanya kenyamanan bagi para konsumen, rasa nyaman akan memberikan suatu motivasi kepada para konsumen untuk melakukan pembelian pada sebuah toko. Menurut Katherine Kolcaba (2013:45), bahwa kenyamanan "sebagai suatu keadaan telah terpenuhinya kebutuhan dasar manusia yang bersifat individual dan holistik." Dengan terpenuhinya kenyamanan, dapat menyebabkan perasaan sejahtera pada diri individu tersebut. Ketika seorang konsumen merasa nyaman maka konsumen akan mengingat kesan nyaman pada sebuah toko yang pernah mereka kunjungi.

Pelayanan memiliki pengaruh positif terhadap keputusan pembelian konsumen pada Krisna 5 Singaraja. Sejalan dengan pendapat Suparlan (2000:35), pelayanan adalah "usaha pemberian bantuan atau pertolongan kepada orang lain, baik berupa materi maupun non materi agar orang itu dapat mengatasi masalahnya sendiri." Ketika seseorang mendapatkan suatu pelayanan yang baik dan memuaskan dari sebuah toko, maka akan tertanam suatu ingatan kesan yang baik mengenai pelayanan suatu toko diingatan konsumen, sehingga ketika konsumen hendak membeli produk atau suatu kebutuhan maka konsumen akan datang kembali untuk melakukan pembelian pada toko tersebut.

Dalam rangka menciptakan kepuasan terhadap konsumen, produk atau jasa yang ditawarkan harus berkualitas. Dengan memberikan pelayanan yang berkualitas dapat mendongkrak penjualan jasa dan menciptakan keunggulan tersendiri dibandingkan pesaing. Suatu kualitas 
yang baik harus dimulai dari kebutuhan pelanggan dan berakhir pada persepsi pelanggan sehingga ketika pelanggan memiliki persepsi yang baik terhadap pelayanan sebuah perusahaan atau toko maka pelanggan akan memiliki keinginan melakukan keputusan pembelian kembali pada toko tersebut.

\section{SIMPULAN DAN SARAN Simpulan}

Berdasarkan hasil penelitian dan pembahasan, maka dapat disimpulkan sebagai berikut bahwasanya fasilitas fisik berpengaruh signifikan terhadap keputusan pembelian konsumen Krisna 5 Singaraja. Hal tersebut ditunjukkan dari hasil analisis ttes yang menunjukkan bahwa nilai thitung $=6.681>t_{\text {tabel }}=1.66$ atau $\mathrm{p}$-value $=0.000<\alpha=0.05$, kedua Barang dagangan berpengaruh signifikan terhadap keputusan pembelian konsumen pada Krisna 5 Singaraja. Hal tersebut ditunjukkan dari hasil analisis ttes yang menunjukkan bahwa nilai thitung $=$ $1.523>t_{\text {tabel }}=1.66$ atau $p$-value $=$ $0.000<\alpha=0.05$. Kenyamanan berpengaruh signifikan terhadap keputusan pembelian konsumen pada Krisna 5 Singaraja. Hal tersebut ditunjukkan dari hasil analisis ttes yang menunjukkan bahwa nilai thitung = $14.130>t_{\text {tabel }}=1.66$ atau $p$-value $=$ $0.000<\alpha=0.05$. Pelayanan berpengaruh signifikan terhadap keputusan pembelian konsumen pada Krisna 5 Singaraja. Hal tersebut ditunjukkan dari hasil analisis ttes yang menunjukkan bahwa nilai thitung $=1.898$ $>t_{\text {tabel }}=1.66$ atau $p$-value $=0.000<\alpha$ $=0.05$, dan fasilitas fisik, barang dagangan, kenyamanan dan pelayanan berpengaruh signifikan terhadap keputusan pembelian konsumen pada Krisna 5 Singaraja. Hal tersebut ditunjukkan dari hasil analisis Ftes yang menunjukkan bahwa nilai bahwa $F_{\text {hitung }}=$ $121.745>F_{\text {tabel }}=2.47$ atau $p$-value $=$ $0.000<\alpha=0,05$. Besarnya pengaruh dari variabel fasilitas fisik, barang dagangan, kenyamanan dan pelayanan terhadap kepuasan kerja adalah sebesar $83 \%$ sedangkan sisanya sebesar $17 \%$ dipengaruhi oleh faktor lain yang tidak termasuk dalam penelitian ini.

\section{Saran}

Berdasarkan simpulan di atas, maka dapat dikemukakan saran sebagai berikut.

Bagi perusahaan hasil penelitian ini dapat digunakan sebagai evaluasi dan mengetahui pengaruh dari pengadaan fasilitas fisik, produk atau barang dagangan yang dijual serta peningkatan kenyamanan konsumen dengan cara pengadaan kamera pemantau, security, dan penataan produk dengan rapi serta peningkatan pelayanan karyawan dalam melayani konsumen, memberikan salam sapa kepada konsumen, dan membantu konsumen dalam menemukan produk yang sulit dijangkau, sehingga konsumen merasakan kesan yang baik dari perusahaan dan mampu membuat konsumen untuk melakukan keputusan pembelian kembali pada perusahaan.

Bagi peneliti lain yang bermaksud melakukan penelitian di bidang keputusan pembelian konsumen khususnya yang tertarik dan berminat untuk mendalami tentang store image yang mencakup fasilitas fisik, barang dagangan atau produk serta kenyamanan dan pelayanan, diharapkan untuk mengembangkan penelitian ini dengan menambah sampel atau populasi yang lebih luas agar dapat menguji variabel lain yang diduga kuat dapat mempengaruhi keputusan pembelian konsumen.dapat mempengaruhi keputusan pembelian konsumen.

\section{Daftar Pustaka}

Alma, Buchari. 2003. Manajemen Pemasaran Dan Pemasaran Jasa. Bandung: CV Alfabeta..

Berman, B and Evans. 2001. Retail Management A Strategic Approach. New Jersey: Prentice Hall.

Cox, Roger, \& Paul Brittian. 2004. Retailing an Introduction. Fifth edition. New York: Prentice Hall.

Darsono. 2001. Belajar dan Pembelajaran. Semarang: IKIP Semarang Press.

Kolcaba, Katherine. (2003). Comfort Theory And Practice: A Vision For Holistic. New Jersey: Prentice Hall.

Kotler, Philip. 2002. Manajemen Pemasaran, Analisis, Perencanaan, Implementasi dan Kontrol. 
Terjemahan. Edisi Millenium. Jakarta: Prenhallindo..

Maxwell, K \& Swanson scott. 2009.

Grocery Store Image, Travel

Distance, Statisfaction, and Behavioral Intentions. International Jurnal of Retail \& Distribution Management. Emerald Group

Publishing Limited. New York:

Prentice Hall.

Peter \& Olson. 2000. Manajemen Pemasaran. Jakarta: Salemba Empat.

Ruslan, Rosadi. 2008. Manajemen Public Relations \& Media Komunikasi. Jakarta: PT. Raja Grafindo Persada.

Sangadji, E.M \& Sopiah. 2013. Prilaku Konsumen : Pendekatan Praktis Disertai:Himpunan Jurnal Penelitian. Yogyakarta: Penerbit Andi.

Schiffman, Leon G. \& Kanuk, Leslie. 2002. Consumer Behavior Ninth Edition. Pearson Prentice Hall. New York: Prentice Hall.

Simamora, B. 2003. Analisis Multivariat Pemasaran. Jakarta: Gramedia Pustaka Utama.

------. 2008. Panduan Riset Perilaku Konsumen. Cetakan Ke Tiga, Jakarta: Gramedia Pustaka Utama.

Sopian \& Syihabudhi. 2008. Manajemen Bisnis Ritel. Yogyakarta: CV Andi Offset.

Sumayang, Lalu. 2003. Dasar-Dasar Manajemen Produksi dan Operasi . Jakarta: Salemba Empat.

Suwandi, Suparlan. 2000. Perawatan dan pelayanan. Bandung: ITB Bandung

Tjiptono, Fandy. 2004. Manajemen Jasa. Edisi Pertama. Yogyakarta: Andi

Utami, Widya. 2010. Manajemen Ritel. Jakarta: Salemba Empat. 